\title{
Synthesis and anion binding properties of the smallest meso-expanded calix[4]pyrrole
}

\author{
B SATHISH KUMAR and PRADEEPTA K PANDA*(1) \\ School of Chemistry, University of Hyderabad, Hyderabad, Telangana 500 046, India \\ E-mail: pkpsc@uohyd.ernet.in; pradeepta.panda@uohyd.ac.in
}

MS received 14 February 2018; revised 15 March 2018; accepted 19 March 2018; published online 5 July 2018

\begin{abstract}
The smallest core expanded calix[4]pyrrole derivative (5) was synthesized via incorporation of an additional sp $\mathrm{sp}^{3}$ meso-carbon at the periphery of the macrocycle. Anion binding study of the macrocycle reveals clearly the effect of core size on its affinity towards various tested ions $\left(\mathrm{F}^{-}, \mathrm{Cl}^{-}, \mathrm{Br}^{-}, \mathrm{I}^{-}, \mathrm{AcO}^{-}, \mathrm{H}_{2} \mathrm{PO}_{4}^{-}\right.$, $\mathrm{HSO}_{4}^{-}, \mathrm{ClO}_{4}^{-}, \mathrm{PF}_{6}^{-}, \mathrm{NO}_{3}^{-}, \mathrm{NO}_{2}^{-}, \mathrm{N}_{3}^{-}$and $\mathrm{CN}^{-}$). The macrocycle displays the highest affinity towards fluoride and acetate ions, albeit with reduced affinities compared to parent octamethylcalix[4]pyrrole.
\end{abstract}

Keywords. Calix[4]pyrrole; meso-expanded Calix[4]pyrrole; host-guest complex; hydrogen-bond; anion.

\section{Introduction}

The increased attention towards selective recognition of fluoride ion is driven by its applications in environmental and health sectors, especially in dental care and in the treatment of osteoporosis. ${ }^{1}$ As a result, a large number of synthetic receptors containing H-bond donor motifs, Lewis acidic sites and electron deficient organic $\pi$-systems have been designed. ${ }^{2}$ In this direction, calix[4]pyrrole 1 has emerged as an attractive neutral host for anions in the last two decades (Figure 1). ${ }^{3}$ Consequently, a large number of transformations have been effected on the periphery of this macrocycle, including modification of its binding core. ${ }^{4}$ As calix[4]pyrrole $\mathbf{1}$ mostly binds to smaller halide ions, it was anticipated that bigger core size would be more suitable to bind larger anions. The core expansion could be achieved by increasing the number of pyrrolic moieties (increases the number of binding sites for hydrogen bonding) or by incorporation of a spacer between the constituent pyrrolic units. Towards this, in 1997 the first expanded calixpyrrole was reported by Sessler and coworkers, ${ }^{5}$ subsequently, higher calix[n]pyrroles were synthesized. ${ }^{6}$ Further, a new type of expanded calix[4]pyrroles, containing bigger core size, were made by using spacer units viz., carbazole and benzene moieties. ${ }^{7}$ In this regard, recently we have reported calix[2]bispyrrolylethenes (2); among these receptors, 2a displayed colorimetric sensing of fluoride ion in polar aprotic solvents (Figure 1). ${ }^{8} \mathrm{Sim}-$ ilarly, we could also demonstrate fluorometric sensing of fluoride ion by calix[2]bispyrrolylarenes $\mathbf{3 a - b}$ (Figure 1). ${ }^{9}$ However, the calix[2]bispyrrolylarenes, in spite of their close resemblance to calix[2]bispyrrolylethene, display significant affinity towards acetate ion. ${ }^{9}$ Further, recently we reported a new type of meso-expanded calix[4]pyrrole 4 i.e., calix[2]bispyrrolylethane, which stabilizes infinite 1D chain of water molecules in solid state, whose anion binding studies will be reported separately (Figure 1). ${ }^{10}$

Herein, we report the synthesis of a novel mesoexpanded calix[4]pyrrole 5, which belongs to a new class of macrocycle, namely, the smallest expanded calix[4]pyrrole. Further, we have also investigated the anion binding properties of this new macrocycle in both solution and solid states. The objective was to explore the relation between the core size and the anion affinity and selectivity via an incremental change in core size of the parent calix[4]pyrrole $\mathbf{1}$ and subsequently compare their anion binding behavior. In particular, we were interested to know whether the expansion of core size can lead to the specific selectivity of the macrocycle towards fluoride ion.

\footnotetext{
*For correspondence

Electronic supplementary material: The online version of this article (https://doi.org/10.1007/s12039-018-1480-x) contains supplementary material, which is available to authorized users.
} 

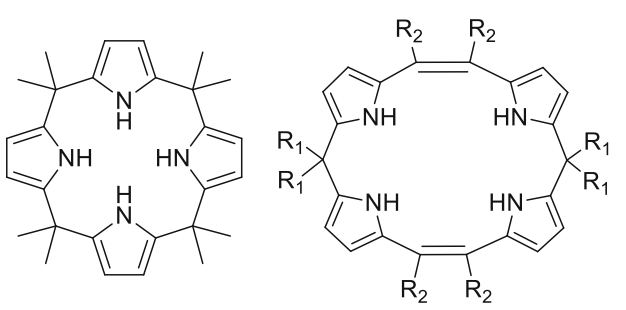

1

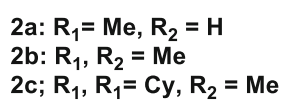

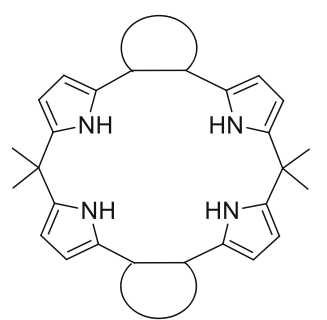

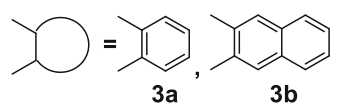

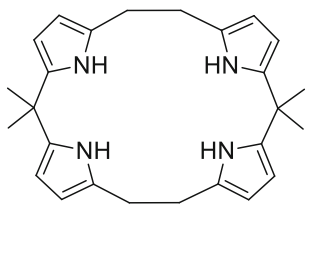

4

Figure 1. Calix[4]pyrrole $\mathbf{1}$ and some of its meso-expanded calix[4]pyrrole analogues (2-4).

\section{Experimental}

\subsection{Materials and physical measurements}

Chemicals, reagents and solvents were purchased from commercially available sources. Solvents were purified with appropriate drying procedure. ${ }^{11}$ All the tetrabutyl ammonium salts and analytical grade solvents for NMR and ITC titration experiments were purchased from Sigma-Aldrich and were directly used in the titration experiments.

Melting points were determined by slides with coverslips on MR-Vis ${ }^{+}$visual melting point range apparatus from LABINDIA Instruments Private limited. IR spectra were recorded on a JASCO FTIR model 5300 and NICOLET 5700 FT-IR spectrometers. LCMS analyses were carried out by Shimadzu-LCMS-2010 mass spectrometer and HRMS data were obtained with Bruker Maxis spectrometer. NMR spectra were recorded on Bruker $400 \mathrm{MHz}$ FT-NMR spectrometer operating at ambient temperature. TMS was used as internal standard for ${ }^{1} \mathrm{H}$ NMR spectra.

\subsection{Synthesis of macrocycle 5}

5,5'-Dimethyldipyrromethane $\mathbf{6}^{12}(108 \mathrm{mg}, 0.625 \mathrm{mmol})$ and bispyrrolylethane (BPE) $7^{10}(100 \mathrm{mg}, 0.625 \mathrm{mmol})$ were dissolved in dry dichloromethane $(20 \mathrm{~mL})$, to this dry acetone $(2.3 \mathrm{~mL}, 0.312 \mathrm{mmol})$ was added under nitrogen atmosphere. Then, boron trifluoride diethyl etherate $(10 \mu \mathrm{L}, 0.156 \mathrm{mmol})$ was added and stirred at room temperature. After $30 \mathrm{~min}$, the starting material was finished and as anticipated, three new spots were observed in TLC. Then, the reaction was stopped by quenching with sat. sodium bicarbonate solution $(5 \mathrm{~mL})$, the organic layer was separated and concentrated in a rotary evaporator, and the crude product was purified by silica gel column chromatography by slow elution with $5-10 \%$ ethyl acetate in hexane. The three products were isolated as $(\mathbf{5}$, $34 \mathrm{mg}, 13 \%),(\mathbf{4}, 30 \mathrm{mg}, 23 \%)$ and $(\mathbf{1}, 17 \mathrm{mg}, 13 \%)$.

Characterization data of compound 5: Melting point: 162 $164^{\circ} \mathrm{C}$ (dec.); FTIR Data (KBr): 3386.91, 2970.97, 1416.85, $1040.00,688.23 \mathrm{~cm}^{-1} .{ }^{1} \mathrm{HNMR}\left(400 \mathrm{MHz}, \mathrm{CDCl}_{3}\right): \delta$ in ppm 7.47 (s, 2H, NH), 7.08 (s, 2H, NH), 5.95-5.89 (m, 6H, pyrrole $\beta$-CH), 5.82-5.80 (brs, $2 \mathrm{H}$, pyrrole $\beta-\mathrm{CH}$ ), 2.81 (brs, $4 \mathrm{H}$, $\left.-\mathrm{CH}_{2}\right), 1.51$ (s, $\left.18 \mathrm{H}, \mathrm{CH}_{3}\right) .{ }^{13} \mathrm{C} \mathrm{NMR}\left(100 \mathrm{MHz}, \mathrm{CDCl}_{3}\right)$ : $\delta$ in ppm 137.91, 137.84, 137.75, 131.71, 104.92, 103.32, $102.82,35.42,35.12,29.16,28.98,26.85$. HRMS m/z calculated for $\left(\mathrm{M}+\mathrm{H}^{+}\right) \mathrm{C}_{27} \mathrm{H}_{35} \mathrm{~N}_{4}$ : 415.2862, found: 415.2856 .

Starting materials $6^{12}$ and $7^{10}$ were synthesized, characterized according to the procedure available in literature, and the characterization data of compounds $4^{10}$ and $\mathbf{1}^{3}$ were matched with the available literature data.

\subsection{Single crystal $X$-ray diffraction analysis}

Crystallographic data for $\mathbf{5}$ was collected on a dual source Oxford Gemini A Ultra diffractometer and $\operatorname{Mo}_{-} \mathrm{K}_{\alpha}(\lambda=$ $0.71073 \AA$ ) radiation was used to collect the X-ray reflections. Data reduction was performed using CrysAlis ${ }^{\text {Pro }}$ 171.33.55 software. ${ }^{13}$ The structure was solved by using Olex2-1.0 with anisotropic displacement parameters for non- $\mathrm{H}$ atoms and final refinement was done by SHELXL2014/7. ${ }^{14}$ Empirical absorption correction was done using spherical harmonics, implemented in SCALE3 ABSPACK scaling algorithm. Crystallographic data for 5.TBACl was collected on BRUKER SMART-APEX CCD diffractometer and $\mathrm{Mo}-\mathrm{K} \alpha(\lambda=0.71073 \AA)$ radiation was used to collect the reflections on the single crystal. Data reduction was performed using Bruker SAINT ${ }^{15}$ software. Intensities for absorption were corrected using SADABS ${ }^{16}$ and refined using SHELXL-2014/7 ${ }^{14}$ with anisotropic displacement parameters for non- $\mathrm{H}$ atoms. Hydrogen atoms on $\mathrm{O}$ and $\mathrm{N}$ were experimentally located in difference electron density maps. All $\mathrm{C}-\mathrm{H}$ atoms were fixed geometrically using HFIX command in SHELX-TL. A check of the final CIF file using PLATON ${ }^{17}$ did not show any missed symmetry (Table 1).

\subsection{Anion binding study}

${ }^{1} \mathrm{H}$ NMR titration studies were carried out in a $400 \mathrm{MHz}$ NMR spectrometer in acetonitrile- $d_{3}\left(0.5 \% \mathrm{v} / \mathrm{v} \mathrm{D}_{2} \mathrm{O}\right.$ in case of fluoride ion) solvent at $25^{\circ} \mathrm{C}$. All anions were used in the form of their tetrabutylammonium (TBA) salts (fluoride salt as its trihydrate). The receptor solutions were titrated by adding known quantities of a concentrated solution of the anions in question. The anion solution used to effect the titrations contained the receptor at the same concentration as the receptor solutions into which they were being titrated. The data 
Table 1. Crystallographic data and structure refinement information.

\begin{tabular}{|c|c|c|}
\hline Compound & 5.EtOAc & $5 \cdot \mathrm{TBACl}$ \\
\hline Formula & $\mathrm{C}_{31} \mathrm{H}_{42} \mathrm{~N}_{4} \mathrm{O}_{2}$ & $\mathrm{C}_{43} \mathrm{H}_{70} \mathrm{Cl} \mathrm{N}_{5}$ \\
\hline Formula weight & 502.69 & 692.49 \\
\hline Color & Colorless & Colorless \\
\hline Temperature & 293(2) K & 298(2) K \\
\hline Wavelength & $0.71073 \AA$ & $0.71073 \AA$ \\
\hline Crystal system & Triclinic & Monoclinic \\
\hline Space group & $P-1$ & $C c$ \\
\hline \multirow[t]{4}{*}{ Unit cell dimensions } & $\mathrm{a}=11.031(3) \AA, \alpha=105.86(2)^{\circ}$ & $\mathrm{a}=11.604(4) \AA, \alpha=90^{\circ}$ \\
\hline & $\mathrm{b}=12.413(3) \AA, \beta=107.21(2)^{\circ}$ & $\mathrm{b}=19.303(6) \AA$ \\
\hline & $c=12.599(3) \AA, v=106.45(2)^{\circ}$ & $\mathrm{c}=19.312(6) \AA, v=90^{\circ}$ \\
\hline & Volume $=1455.4(6) \AA^{3}$ & Volume $=4320(2) \AA^{3}$ \\
\hline $\mathrm{Z}$ & 2 & 4 \\
\hline Density (calculated) & $1.147 \mathrm{~g} / \mathrm{cm}^{3}$ & $1.065 \mathrm{~g} / \mathrm{cm}^{3}$ \\
\hline Absorption coefficient & $0.072 \mathrm{~mm}^{-1}$ & $0.122 \mathrm{~mm}^{-1}$ \\
\hline $\mathrm{F}(000)$ & 544 & 1520 \\
\hline Crystal size & $0.21 \times 0.20 \times 0.16 \mathrm{~mm}^{3}$ & $0.28 \times 0.27 \times 0.25 \mathrm{~mm}^{3}$ \\
\hline Theta range for data collection & 2.77 to $24.30^{\circ}$ & 2.05 to $26.63^{\circ}$ \\
\hline Index ranges & $\begin{array}{c}-12 \leq \mathrm{h} \leq 12,-11 \leq \mathrm{k} \leq 14 \\
-14 \leq 1 \leq 11\end{array}$ & $\begin{array}{c}-14 \leq \mathrm{h} \leq 14,-24 \leq \mathrm{k} \leq 24 \\
-24 \leq 1 \leq 24\end{array}$ \\
\hline Reflections collected & 8599 & $2 \overline{2} 47 \overline{3}$ \\
\hline Independent reflections & $4735[\mathrm{R}(\mathrm{int})=0.1958]$ & $8835[\mathrm{R}(\mathrm{int})=0.1252]$ \\
\hline Completeness to theta & $99.9 \%\left(\theta 24.30^{\circ}\right)$ & $98.7 \%\left(\theta 25.242^{\circ}\right)$ \\
\hline Absorption correction & Semi-empirical from equivalents & Semi-empirical from equivalents \\
\hline Max. and min. transmission & 0.989 and 0.985 & 0.970 and 0.966 \\
\hline Refinement method & Full-matrix least-squares on $\mathrm{F}^{2}$ & Full-matrix least-squares on $\mathrm{F}^{2}$ \\
\hline Data/restraints/parameters & $4735 / 13 / 344$ & $8835 / 10 / 436$ \\
\hline Goodness-of-fit on $\mathrm{F}^{2}$ & 0.917 & 0.944 \\
\hline Final $R$ indices $[\mathrm{I}>2 \operatorname{sigma}(\mathrm{I})]$ & $\mathrm{R} 1=0.1301, \mathrm{wR} 2=0.3054$ & $\mathrm{R} 1=0.1079, \mathrm{wR} 2=0.2485$ \\
\hline $\mathrm{R}$ indices (all data) & $\mathrm{R} 1=0.3476, \mathrm{wR} 2=0.4073$ & $\mathrm{R} 1=0.3097, \mathrm{wR} 2=0.3520$ \\
\hline Largest diff. peak and hole & 0.35 and -0.28 e. $\AA^{-3}$ & 0.227 and $-0.201 \mathrm{e} . \AA^{-3}$ \\
\hline
\end{tabular}

were fitted to a $1: 1$ binding profile in MATLAB 7.0 package according to the method of Wilcox ${ }^{18}$ using the changes in the pyrrolic NH resonances in the ${ }^{1} \mathrm{H}$ NMR spectra. Job's plot for host vs. anion was performed in acetonitrile- $d_{3}$ at $25^{\circ} \mathrm{C}$. Equal concentration of compound and anion solution were mixed in ratios from 1:10 to 10:1 and the chemical shift was monitored and noted vs the residual $\mathrm{CD}_{3} \mathrm{CN}$ (1.94 ppm) resonance. In this experiment $\beta-\mathrm{CH}$ proton (in case of TBAF) and $\mathrm{NH}$ proton (in case of other ions) resonances of pyrrole are monitored.

Microcalorimetric titrations were performed using an isothermal titration calorimeter (ITC) purchased from Microcal Inc., MA. The Origin software provided by Microcal Inc. was used to calculate the binding constant $\left(K_{a}\right)$ and the enthalpy change $(\Delta \mathrm{H})$. Host-guest solutions are prepared in $0.5 \%$ water in acetonitrile in case of fluoride as a guest and only in acetonitrile (HPLC grade with $<0.05 \%$ water) in case of other ions. The host solution is about $2-2.5 \mathrm{~mL}$ of required concentration prepared and taken in VPITC cell (volume $\sim 1.44 \mathrm{~mL}$ ), and the corresponding guest solution about $1-2 \mathrm{~mL}$ of required concentration is prepared and taken in VP-ITC syringe (whose volume is $\sim 286 \mu \mathrm{L}$ ). Further, we have checked ITC profile of the basic octamethylcalix[4]pyrrole (1) in presence of TBAF, and $\mathrm{TBACl}$ to confirm the accuracy and reproducibility of performed methods.

\subsection{Computational Calculations}

All DFT structure optimization calculations were done in Gaussian09 software by using B3LYP method 6-31G*(d,p) basis set in the gas phase. ${ }^{19}$ In all these calculations, the host molecule was set in cone conformation and assumed 1:1 complex with respect to anions.

\section{Results and Discussion}

\subsection{Synthesis and characterization of macrocycle 5}

Mixed condensation of 5,5'-dimethyldipyrromethane $6^{12}$ and bispyrrolylethane (BPE) $7^{10}$ with acetone in presence of $\mathrm{BF}_{3} \cdot \mathrm{OEt}_{2}$ or TFA as the acid catalyst 


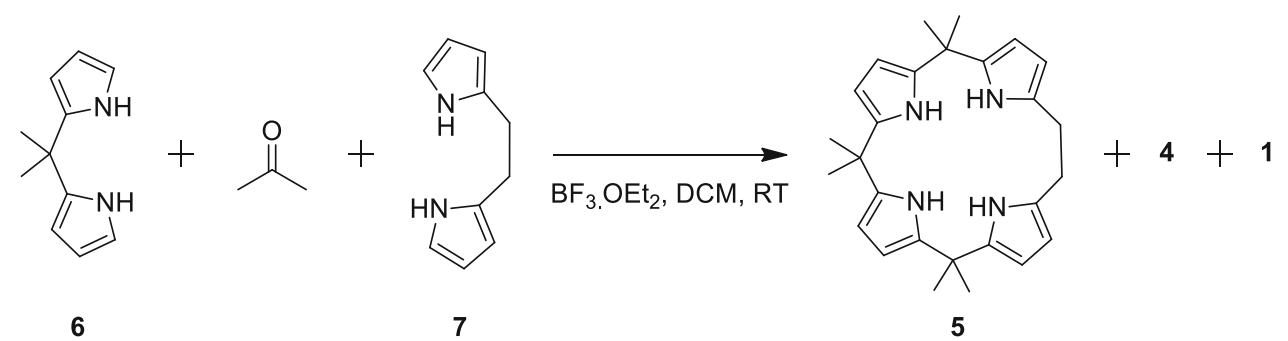

Scheme 1. Synthesis of macrocycle 5.
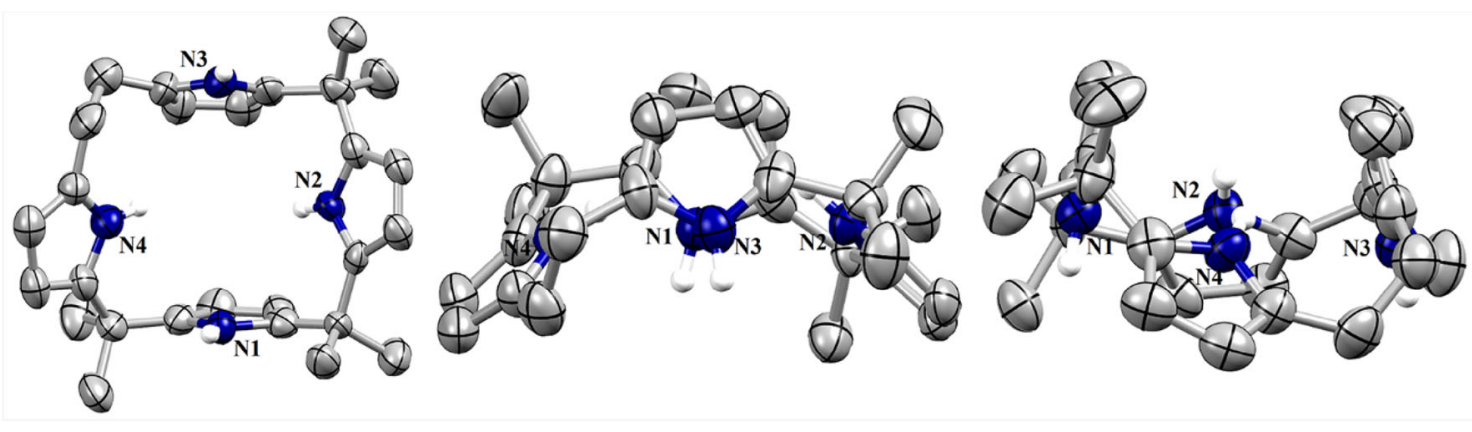

Figure 2. ORTEP-POVray diagram of 5, top view (left) and two different side views (right). Solvent molecule (EtOAc), all hydrogens bound to carbon atom are excluded for clarity. Thermal ellipsoids are scaled upto $35 \%$ probability level. Color code: grey $=$ Carbon, white $=$ Hydrogen and blue $=$ Nitrogen .

(Scheme 1) resulted in the formation of three macrocycles as expected (Scheme 1), where the formation of macrocycle 5 ( $2^{\text {nd }}$ fraction, $13 \%$ ) remain unaltered. However, in the presence of $\mathrm{BF}_{3} \cdot \mathrm{OEt}_{2}$, the reaction completes rapidly (in $30 \mathrm{~min}$ ) with higher yield of macrocycle 4 ( $3^{\text {rd }}$ fraction, 23\%) and lower yield of calix[4]pyrrole 1 ( $1^{\text {st }}$ fraction, 13\%); on the other hand, TFA catalysed reaction needed longer time to complete $(\sim 5 \mathrm{~h})$ and yielded lesser amount of $\mathbf{4}(8 \%)$ and more of $1(17 \%)$. The products formed were rigorously characterized by various spectroscopic tools ( $\mathrm{SI}=$ Supplementary Information).

\subsection{Crystal structure analysis of macrocycle 5}

The semi-expanded macrocycle $\mathbf{5}$ was crystallized by slow evaporation of 5\% ethyl acetate in hexane solution, which resulted in an ethyl acetate solvate (5.EtOAc). The macrocycle 5 adopts 1,3-alternate conformation (Figure 2), similar to the basic octamethylcalix[4]pyrrole $1,{ }^{3}$ with slightly bigger cavity and smaller than meso-expanded calix[4]pyrrole 4. ${ }^{12}$ Further, the two of the opposite pyrrole units (N1 and N3) adopts almost orthogonal geometry with regard to the calixpyrrole core and the alternate NHs are directed in opposite direction with respect to each other [with dihedral angles between the two pyrrole units (N1 and N3) $\sim 22^{\circ}$ ] while, the remaining two pyrroles [with dihedral angles (N2 and N4) is $\sim 21$ to $29^{\circ}$ ] are slightly tilted with their NHs disposed towards the core (because of the flexible ethylene bridge) (Figure 2).

Further, ethylacetate molecule resides as solvate in the crystal lattice with hydrogen bonding interactions, where the carbonyl oxygen of ethyl acetate molecule is $\mathrm{H}$-bonded with one of the pyrrole-NH of the constituent BPE moiety, having N... O distance of 2.99(2) $\AA$, with associated $\mathrm{N}-\mathrm{H} \cdots \mathrm{O}$ angle of $\sim 163^{\circ}$ (Figure S5 in Supplementary Information).

\subsection{Anion binding study of macrocycle 5}

Preliminary solution phase anion binding studies were carried out for macrocycle 5 by using ${ }^{1} \mathrm{H}$ NMR studies in $\mathrm{CD}_{3} \mathrm{CN}$ with various anions viz., $\mathrm{F}^{-}, \mathrm{Cl}^{-}, \mathrm{Br}^{-}, \mathrm{I}^{-}$, $\mathrm{AcO}^{-}, \mathrm{H}_{2} \mathrm{PO}_{4}^{-}, \mathrm{HSO}_{4}^{-}, \mathrm{ClO}_{4}^{-}, \mathrm{PF}_{6}^{-}, \mathrm{NO}_{3}^{-}, \mathrm{NO}_{2}^{-}, \mathrm{N}_{3}^{-}$and $\mathrm{CN}^{-}$as their tetrabutylammonium (TBA) salts and the spectral changes observed indicate moderate to weak binding for most of the ions (Figure S6 in Supplementary Information). On the other hand, perchlorate and hexafluorophosphate ions display no observable interaction with the host. Subsequent detailed analysis by ${ }^{1} \mathrm{H}$ NMR titration and evaluation of association constants were performed by using Wilcox 1:1 binding equation $^{18}$ (Table 2, Figures S7-S15 in Supplementary Information), and stoichiometry confirmed via Job's plot analysis (Figures S16-S19 in Supplementary Information). The data reveal that $\mathbf{5}$ displays maximum affinity towards fluoride and acetate ions but with no 
Table 2. Summary of association constants $K_{a}\left(\mathrm{M}^{-1}\right)$ of receptors 1 and 5 in the presence of different anions obtained from ${ }^{1} \mathrm{H}$ NMR in acetonitrile$d_{3}$ at $22-25^{\circ} \mathrm{C}$.

\begin{tabular}{lcccc}
\hline & TBAF $^{a}$ & TBACl & TBAOAc & TBAH $_{2} \mathrm{PO}_{4}$ \\
\hline 1 & $>10^{4 b}$ & $>5 \times 10^{3 b}$ & N. D. & $1.3 \times 10^{3 b}$ \\
5 & $6.33 \pm 2.9 \times 10^{3}$ & $9.5 \pm 1.4 \times 10^{3}$ & $>10^{4}$ & $6.46 \pm 2.2 \times 10^{3}$ \\
\hline ' $a$ ' = in acetonitrile- $d_{3}\left(0.5 \% \mathrm{v} / \mathrm{v} \mathrm{D}{ }_{2} \mathrm{O}\right)$ at $22^{\circ} \mathrm{C} ;{ }^{\prime} b$ ' $=$ from ref ${ }^{20} ;$ 'N. D.' \\
$=$ not determined.
\end{tabular}

Table 3. Summary of thermodynamic parameters of different anions with receptors $\mathbf{1}$ and $\mathbf{5}$ obtained from ITC in acetonitrile at $30^{\circ} \mathrm{C}$.

\begin{tabular}{lccccc}
\hline Host & Guest & $\Delta \mathrm{H}(\mathrm{kcal} / \mathrm{mol})$ & $\mathrm{T} \Delta \mathrm{S}(\mathrm{kcal} / \mathrm{mol})$ & $\Delta \mathrm{G}(\mathrm{kcal} / \mathrm{mol})$ & $K_{a}\left(\mathrm{M}^{-1}\right)$ \\
\hline 1 & TBAF $(0.5 \%$ water in Acetonitrile $)$ & $-4.3 \pm 0.03$ & 2.99 & -7.39 & $1.82 \pm 0.13 \times 10^{5}$ \\
5 & & $-3.52 \pm 0.11$ & 1.85 & -5.37 & $7.61 \pm 0.54 \times 10^{3}$ \\
$1^{a}$ & TBACl & $1.4 \times 10^{5}$ & & & \\
5 & & $-4.65 \pm 0.13$ & 0.92 & -5.57 & $1.04 \pm 0.07 \times 10^{4}$ \\
$1^{b}$ & TBAH $_{2} \mathbf{P O}_{4}$ & -11.60 & -5.81 & -5.79 & $1.51 \pm \times 10^{4}$ \\
5 & & $-7.6 \pm 0.21$ & -2.08 & -5.50 & $9.26 \pm 0.62 \times 10^{3}$ \\
$1^{c}$ & TBAOAc & $-11.62 \pm 0.08$ & -4.03 & -7.60 & $2.90 \times 10^{5}$ \\
7 & & $-11.55 \pm 0.17$ & -5.06 & -6.48 & $4.76 \pm 0.41 \times 10^{4}$ \\
\hline
\end{tabular}

$a, b$ and $c$ : from refs. ${ }^{22},{ }^{21 \mathrm{a}}$ and ${ }^{23}$, respectively (recorded in acetonitrile); All the experiments were performed for minimum three times and the obtained values are reproducible within $\pm 15 \%$ error.

clear selectivity towards any other anions like the parent calix[4]pyrrole 1 (Table 2). Interestingly, the distinct characteristic of the two pyrrolic $\mathbf{N H}$ signals of the $\mathbf{5}$ is retained even after complexation with anions except in the case of dihydrogenphosphate ion (only at very high anion concentration one peak was observed), indicating the differential strength of interaction of the two sets of NHs with the incoming anions (Figures S6 and S12 in Supplementary Information). Further, ${ }^{1} \mathrm{H}$ NMR competition experiment reveals calixpyrrole 5 has superior affinity towards fluoride ion over chloride and acetate ions (Figures S20-S21 in Supplementary Information) in identical conditions, similar to the one noticed in case of calixpyrrole $\mathbf{1}$.

These complexation processes were further subjected to isothermal titration calorimetric (ITC) experiments, to evaluate the energetics of the overall binding event ${ }^{21}$ and the corresponding association constants are briefly summarized in Table 3 (Figures S22-S26 in Supplementary Information).

The above studies clearly reveal that receptor 5 displays a better preference towards fluoride and acetate ions, albeit with reduced affinity compared to $\mathbf{1}$, and also shows a relatively weaker affinity towards chloride and dihydrogen phosphate ions.

Several attempts to obtain diffraction grade crystals of the host-guest complexes of the calix[4]pyrrole derivative 5 with anions were made. Slow evaporation of compound $\mathbf{5}$ from its acetonitrile solution, in presence of excess TBACl, resulted in the successful isolation of the diffraction grade crystals of chloride complex. The macrocycle $\mathbf{5}$ adopts an irregular cone conformation (owing to its inherent structure), with all the four pyrrolic NHs hydrogen bonded with the chloride ion (Figure 3). As a result of this irregular cone structure, one of the pyrrolic $\mathrm{NH}$ of the BPE constituent resides closest to the anion (N3-Cl distance 3.26(2) $\AA$ ), whereas the other pyrrolic $\mathrm{NH}$ of the BPE moiety resides at the farthest (N4-Cl distance 3.42(2) $\AA$ ) and the pyrrole unit opposite to it (N1-Cl distance 3.31(1) $\AA$ ) and adjacent to it from the dipyrromethane constituent (N2-Cl distance 3.38(1) A), residing at intermediate lengths. This also confirmed the slightly bigger and unsymmetrical nature of the binding domain of calix[4]pyrrole 5 than $\mathbf{1}(\mathrm{N}-\mathrm{Cl}$ distance $3.26-3.33 \AA$ ). ${ }^{3 \mathrm{~b}}$

To further understand the reason behind the preference in binding behavior of the semi-expanded calix[4] pyrrole 5 towards fluoride and acetate ions among tested ions, density functional theory (DFT) calculations for the structure optimization with respective anions were performed (Figures 4, S27-S29 in Supplementary Information), which reveal the favorable binding nature of different anions (Table S1 in Supplementary Information). ${ }^{19}$ For example, the hybrid macrocycle 5 displays good affinity towards acetate ion and the optimized structure of $\mathbf{5}$ with acetate ion supports well and reveals 

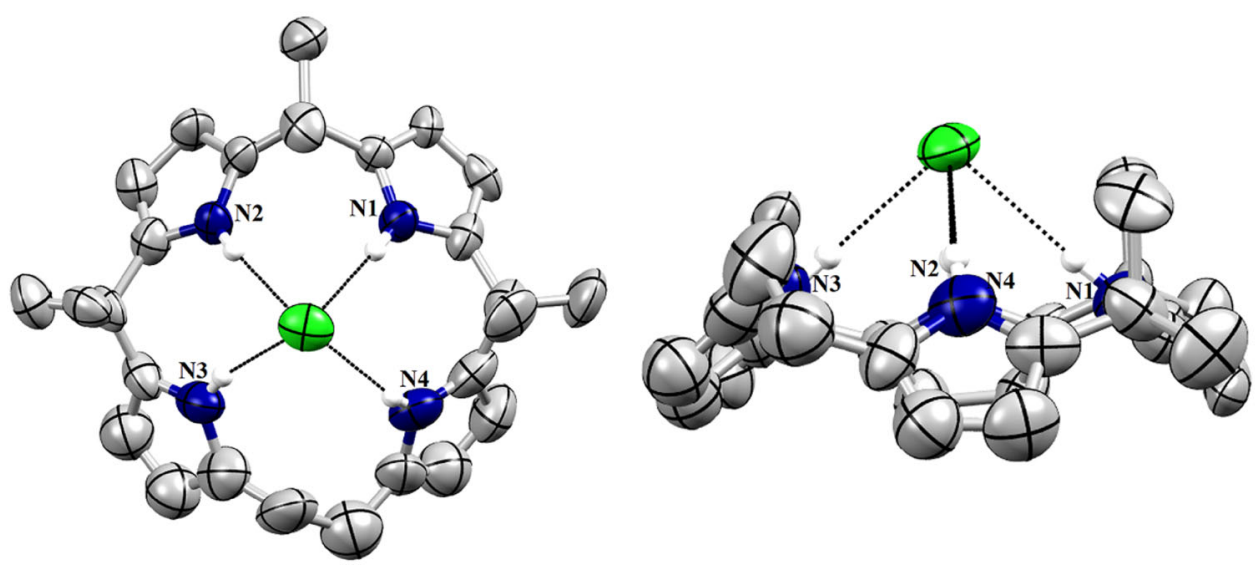

Figure 3. ORTEP-POVray diagram of 5.TBACI complex: top view (left) and side view (right). Tetrabutylammonium cation and all hydrogens bound to carbon atoms are excluded for clarity, and thermal ellipsoids are scaled up to $35 \%$ probability level. Color code: blue: Nitrogen, grey: Carbon, white: Hydrogen and green: Chloride; hydrogen bonds are shown as black dashed lines.
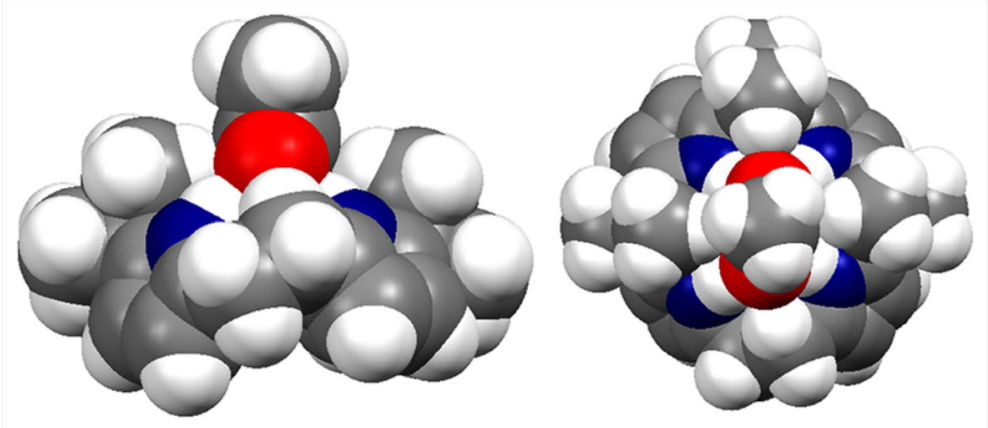

Figure 4. Space filled diagram of DFT optimized structure of 5.AcO ${ }^{-}$ complex in two different views. Color code: grey: Carbon, white: Hydrogen, blue: Nitrogen and red: Oxygen.

its greater fit of binding of both oxygens of anion with pyrrolic NHs of the macrocycle, possibly indicating the reason behind the greater affinity (Figure 4).

\section{Conclusions}

We have designed and synthesized a new meso-expanded calix[4]pyrrole receptor, which belongs to the first example of a new class of smallest expanded calix[4] pyrrole. This macrocycle is endowed with a slightly bigger binding domain, which is also unsymmetric in nature compared to the parent calix[4]pyrrole moiety. This resulted in relatively reduced anion affinities of this macrocycle compared to the latter. However, exclusive selectivity towards fluoride ion could not be achieved and at present efforts are directed towards this. The new macrocycle displays highest affinity towards fluoride and acetate ions among the tested ions.

\section{Supplementary Information (SI)}

Crystallographic data (including the structure factor files) for structures $\mathbf{5}$ and 5.TBACl in this paper have been deposited in the Cambridge Crystallographic Data Centre as supplementary publication numbers CCDC 1017831 and 1017832 , respectively. Copies of the data can be obtained free of charge on application to CCDC, 12 Union Road, Cambridge CB2 1EZ, UK (Fax: +44(0)-1223-336033 or e-mail: deposit@ccdc.cam.ac.uk). Compound characterization, ${ }^{1} \mathrm{H}$ NMR titration, ITC and computational data are available as Supplementary Information at www.ias.ac.in/chemsci.

\section{Acknowledgements}

This work was supported by CSIR, India (Project no. 01 (2449)/10/EMR-II) and SERB, India (Project no. SB/S1/IC56/2012). Financial and infrastructure support from the UGC, New Delhi (through the UPE and CAS programs) and the DST, New Delhi (through the PURSE and FIST programs) are gratefully acknowledged. Authors thank Center 
for Modelling, Simulation and Design (CMSD), University of Hyderabad, Hyderabad, India for computational facility. BSK thanks CSIR and DST India for the fellowship.

\section{References}

1. Matsuo S, Kiyomiya K and Kurebe M 1998 Mechanism of toxic action of fluoride in dental fluorosis: whether trimeric $\mathrm{G}$ proteins participate in the disturbance of intracellular transport of secretory ameloblast exposed to fluoride Arch. Toxicol. 72798

2. (a) Takeuchi M, Shioya T and Swager T M 2001 Allosteric Fluoride Anion Recognition by a Doubly Strapped Porphyrin Angew. Chem. Int. Edit. 40 3372; (b) Mizuno $\mathrm{T}$, Wei W-H, Eller L R and Sessler J L 2002 Phenanthroline Complexes Bearing Fused Dipyrrolylquinoxaline Anion Recognition Sites: Efficient Fluoride Anion Receptors J. Am. Chem. Soc. 124 1134; (c) Jose D A, Kumar D K, Ganguly B and Das A 2004 Efficient and Simple Colorimetric Fluoride Ion Sensor Based on Receptors Having Urea and Thiourea Binding Sites Org. Lett. 6 3445; (d) Gomez D E, Fabbrizzi L and Licchelli M 2005 Why, on Interaction of Urea-Based Receptors with Fluoride, Beautiful Colors Develop J. Org. Chem. 70 5717; (e) Cametti M and Rissanen K 2009 Recognition and sensing of fluoride anion Chem. Commun. 2809; (f) Jeong S-D, NowakKrol A, Kim Y, Kim S-J, Gryko D T and Lee C-H 2010 meso-Alkylidene (m-benzi)pentaphyrin: a modified pentaphyrin bearing exocyclic double bonds at meso-positions Chem. Commun. 46 8737; (g) Wade C R, Broomsgrove A E J, Aldridge S and Gabbai F P 2010 Fluoride Ion Complexation and Sensing Using Organoboron Compounds Chem. Rev. 110 3958; (h) Sokkolingam P and Lee C-H 2011 Highly Sensitive Fluorescence "Turn-On" Indicator for Fluoride Anion with Remarkable Selectivity in Organic and Aqueous Media J. Org. Chem. 76 3820; (i) Mahanta S P and Panda P K 2017 Bis(Pyrrole-benzimidazole) conjugates as novel colorimetric sensor for anions J. Chem. Sci. 129647

3. (a) Baeyer A 1886 Adolf Baeyer: Ueber ein Condensationsproduct von Pyrrol mit Aceton Ber. Dtsch. Chem. Ges. 19 2184; (b) Gale P A, Sessler J L, Kral V and Lynch V 1996 Calix[4]pyrroles: Old Yet New Anion-Binding Agents J. Am. Chem. Soc. 1185140

4. (a) Gale P A, Sessler J L and Kral V 1998 Calixpyrroles Chem. Commun. 1; (b) Sessler J L Anzenbacher P Jr, Jursikova K, Miyaji H, Genge J W, Tvermoes N A, Allen W E and Shiver J A 1998 Functionalized calix[4]pyrroles Pure Appl. Chem. 70 2401; (c) Gale P A, Anzenbacher P Jr and Sessler J L 2001 Calixpyrroles II Coord. Chem. Rev. 222 57; (d) Kim D S and Sessler J L 2015 Calix[4]pyrroles: versatile molecular containers with ion transport, recognition, and molecular switching functions Chem. Soc. Rev. 44 532; (e) Ding Y, Zhu W -H and Xie Y 2017 Development of Ion Chemosensors Based on Porphyrin Analogues Chem. Rev. 1172203

5. Gale P A, Genge J W, Kral V, McKervey M A, Sessler J L and Walker A 1997 First Synthesis of an Expanded Calixpyrrole Tetrahedron Lett. 388443
6. (a) Turner B, Botoshansky $\mathrm{M}$ and Eichen $\mathrm{Y}$ 1998 Extended Calixpyrroles: meso-Substituted Calix[6]pyrroles Angew. Chem. Int. Ed. 37 2475; (b) Sessler J L, Anzenbacher P Jr, Shriver J A, Jursikova K, Lynch V M and Marquez M 2000 Direct Synthesis of Expanded Fluorinated Calix[n]pyrroles: Decafluorocalix[5]pyrrole and Hexadecafluorocalix[8]pyrrole J. Am. Chem. Soc. 122 12061; (c) Cafeo G, Kohenke F H, Torre G L La, White A J P and Williams D J 2000 From Large Furan-Based Calixarenes to Calixpyrroles and Calix[n]furan[m]pyrroles: Syntheses and Structures Angew. Chem. Int. Edit. 39 1496; (d) Jang Y-S, Kim H-J, Lee P-H and Lee C-H 2000 Synthesis of calix[n]furano[n]pyrroles and calix[n]thieno[n]pyrroles $(n=2,3,4)$ by ' $3+1$ ' approach Tetrahedron Lett. 41 2919; (e) Nagarajan A, Jang Y-S and Lee C-H 2000 Convenient Route to Super-Expanded Calixpyrroles: Synthesis of Calix[n]furano[m]pyrroles $(n=3,4,6$, 8 and $\mathrm{m}=2$, 4) Org. Lett. 2 3115; (f) Nagarajan A, Ka J W and Lee C-H 2001 Synthesis of expanded calix[n]pyrroles and their furan or thiophene analogues Tetrahedron 57 7323; (g) Cafeo G, Kohnke F H, Parisi M F, Nascone R P, Torre G L La and Williams D J 2002 The Elusive $\beta$-Unsubstituted Calix[5]pyrrole Finally Captured Org. Lett. 4 2695; (h) Lee E C, Park Y-K, Kim J-H, Hwang H, Kim Y-R and Lee C-H 2002 Bithiophene-containing super-expanded calixpyrrole analogues Tetrahedron Lett. 43 9493; (i) Sessler J L, An D, Cho W-S and Lynch V 2003 Calix[n]bipyrroles: Synthesis, Characterization, and Anion-Binding Studies Angew. Chem. Int. Edit. 42 2278; (j) Sessler J L, Cho W -S, Gross D E, Shriver J A, Lynch V M and Marquez M 2005 Anion Binding Studies of Fluorinated Expanded Calixpyrroles J. Org. Chem. 70 5982; (k) Bruno G, Cafeo G, Kohnke F H and Nicolo F 2007 Tuning the anion binding properties of calixpyrroles by means of $p$-nitrophenyl substituents at their meso-positions Tetrahedron 63 10003; (1) Medrano M B, -Garcia L C, -Celedon C A C and -Garcia J C 2011 Synthesis of a new calix[n]pyrrole: meso-pentaspirocyclohexyl calix[5]pyrrole Tetrahedron Lett. 52 136; (m) Park J S, Bejger C, Larsen K R, Nielsen K A, Jana A, Lynch V M, Jeppesen J O, Kim D and Sessler J L 2012 Synthesis and recognition properties of higher order tetrathiafulvalene (TTF) calix[n]pyrroles $(n=4-6)$ Chem. Sci. 3 2685

7. (a) Piatek P, Lynch V M and Sessler J L 2004 Calix[4]pyrrole[2]carbazole: A New Kind of Expanded Calixpyrrole J. Am. Chem. Soc. 126 16073; (b) Sessler J L, An D, Cho W-S, Lynch V and Marquez M 2005 Calix[n]bispyrrolylbenzenes: Synthesis, Characterization, and Preliminary Anion Binding Studies Chem. Eur. J. 11 2001; (c) Cafeo G, Kohnke F H, White A J P, Garozzo D and Messina A 2007 Syntheses, Structures, and Anion-Binding Properties of Two Novel Calix[2]benzo[4]pyrroles Chem. Eur. J. 13 649; (d) Pushina M, Koutnik P, Nishiyabu R, Minami T, Savechenkov P and Anzenbacher P 2018 Anion Sensing by Fluorescent Expanded Calixpyrroles Chem. Eur. J. 244879

8. Mahanta S P, Kumar B S, Baskaran S, Sivasankar Ch and Panda P K 2012 Colorimetric Sensing of Fluoride 
Ion by New Expanded Calix[4]pyrrole through Anion- $\pi$ Interaction Org. Lett. 14548

9. Chandra B, Mahanta S P, Pati N N, Baskaran S, Kanaparthi R K, Sivasankar C and Panda P K 2013 Calix[2]bispyrrolylarenes: New Expanded Calix[4]pyrroles for Fluorometric Sensing of Anions via Extended $\pi$-Conjugation Org. Lett. 15306

10. Kumar B S and Panda P K 2014 1D water chain stabilized by meso-expanded calix[4]pyrrole CrystEngComm 168669

11. Armarego W L F and Chai C 2003 In Purification of laboratory chemicals $6^{\text {th }}$ edn. (Burkington: Elsevier)

12. Littler B J, Miller M A, Hung C-H, Wagner R W, O'Shea D F, Boyle P D and Lindsey J S 1999 Refined Synthesis of 5-Substituted Dipyrromethanes J. Org. Chem. 641391

13. Oxford Diffraction. CrysAlis CCD and CrysAlis RED. Version 1.171.33.55. Oxford Diffraction Ltd, Yarnton, Oxfordshire, England 2008

14. SHELXL - Version 2014/7; Program for the Solution and Refinement of Crystal Structures, University of Göttingen, Germany, 1993-2014

15. SAINT, version $6.45 / 8 / 6 / 03$ and version $8.34 \mathrm{~A}$, Bruker AXS, 2003-2014

16. Sheldrick G M SADABS and SADABS 2014/5, Program for Empirical Absorption Correction of Area Detector Data, University of Göttingen, Germany, 19972014

17. (a) Spek A L PLATON, A Multipurpose Crystallographic Tool, Utrecht University, Utrecht, The Netherlands, 1980-2016; (b) Spek A L 2009 Acta Cryst. D65 148
18. Wilcox C S 1991 In Frontiers in Supramolecular Organic Chemistry and Photochemistry H-J Schneider (Ed.) (Weinheim: VCH) p. 123

19. Gaussian 09, (Revision C.01), Frisch M J et al. Gaussian, Inc., Wallingford CT, 2010. For full reference see the Supplementary Information.

20. Anzenbacher P Jr, Jursikova K, Lynch V M, Gale P A and Sessler J L 1999 Calix[4]pyrroles Containing Deep Cavities and Fixed Walls. Synthesis, Structural Studies, and Anion Binding Properties of the Isomeric Products Derived from the Condensation of $p$ Hydroxyacetophenone and Pyrrole J. Am. Chem. Soc. 12111020

21. (a) Schmidtchen F P 2002 Surprises in the Energetics of Host-Guest Anion Binding to Calix[4]pyrrole Org. Lett. 4 431; (b) Sessler J L, Gross D E, Cho W-S, Lynch V M, Schmidtchen F P, Bates G W, Light M E and Gale P A 2006 Calix[4]pyrrole as a Chloride Anion Receptor: Solvent and Countercation Effects J. Am. Chem. Soc. 128 12281

22. Sessler J L, An D, Cho W-S and Lynch V 2003 Calix[2]bipyrrole[2]furan and Calix[2]bipyrrole [2]thiophene: New Pyrrolic Receptors Exhibiting a Preference for Carboxylate Anions Angew. Chem. Int. Ed. 42 2278

23. Sessler J L, An D, Cho W-S and Lynch V 2003 Calix[2]bipyrrole[2]furan and Calix[2]bipyrrole [2]thiophene: New Pyrrolic Receptors Exhibiting a Preference for Carboxylate Anions J. Am. Chem. Soc. 125 13646 